\title{
GAMBARAN KONSEP DIRI DAN KECEMASAN PADA ORANG TUA \\ YANG MEMILIKI ANAK RETARDASI MENTAL DI SEKOLAH LUAR BIASA B-C KURNIA KABUPATEN GARUT
}

\author{
Lusi Aprianti, Ali Musthofa, Cucu Rokayah \\ Email: lusiaprianti09@gmail.com
}

Program Studi Sarjana Keperawatan Sekolah Tinggi Ilmu Kesehatan Bandung

\begin{abstract}
Mental retardation is a weakness of mind with intelligence less than period of development from birth, children with mental retardation need more attention and support from parents, because children with mental retardation have a high degree of dependence on parents to meet their needs, whereas happen to parents who have children with mental retardation increased burden on parent, it could trigger emergence of psychosocial problems such change self concept and anxiety. This research conducted to determine the self concept and anxiety in parents who have children with mental retardation in Special School B-C Kurnia Garut. .

This research use quantitative descriptive method with cross sectional approach, population in this research 54 with total sampling technique, instrument used in form of self concept questionnaire that has been standardized with validity test value 0,66 and Dass anxiety questionnaire.

The results showed that $70.9 \%$ of parents have positive self-concept and $45.5 \%$ of parents have moderate anxiety.

The conclusion of this research is that parents who have children with mental retardation have positive self-concept and have moderate anxiety. Suggestions for parents who experience moderate anxiety levels that health workers should provide motivation and information in the form of counseling about the children mental retardation health and expected to family members could provide more support and attention to parents who have children with mental retardation.
\end{abstract}

Keywords: Anxiety, Mental Retardatio, Self Concept

\begin{abstract}
ABSTRAK
Retardasi mental merupakan kelemahan jiwa dengan intelegensi yang kurang dari masa perkembangan sejak lahir, anak dengan retardasi mental perlu mendapatkan perhatian serta dukungan yang lebih dari orang tua, karena anak dengan retardasi mental memiliki tingkat ketergantungan terhadap orang tua untuk memenuhi kebutuhannya, sedangkan yang terjadi pada orang tua yang memiliki anak retardasi mental mengalami peningkatan beban orang tua, hal tersebut dapat memicu munculnya masalah psikososial yaitu perubahan konsep diri dan kecemasan. Penelitian ini dilakukan dengan tujuan untuk mengetahui gambaran konsep diri dan kecemasan pada orang tua yang memiliki anak retardasi mental di Sekolah Luar Biasa B-C Kurnia Kabupaten Garut. Penelitian ini menggunakan metode deskriptif kuantitatif dengan pendekatan cross sectional, populasi dalam penelitian ini sebanyak 54 dengan teknik total sampling, instrumen yang digunakan berupa kuesioner konsep diri yang telah baku dengan nilai uji validitasnya 0,66 dan kuesioner kecemasan Dass. Hasil penelitian menunjukkan 70,9\% orang tua mempunyai konsep diri positif. $45,5 \%$ orang tua memiliki kecemasan sedang. Kesimpulan dari penelitian ini adalah orang tua yang memiliki anak retardasi mental mempunyai konsep diri positif dan memiliki kecemasan sedang. Saran bagi petugas kesehatan harus memberikan motivasi dan informasi berupa penyuluhan tentang kesehatan anak retardasi mental dan diharapkan anggota keluarga dapat lebih memberikan dukungan dan perhatian pada orang tua yang memiliki anak retardasi mental.
\end{abstract}

Kata-kata kunci: Konsep Diri, Kecemasan, Retardasi Mental 


\section{PENDAHULUAN}

Anak merupakan individu yang berada dalam suatu rentang perubahan perkembangan yang dimulai dari bayi hingga remaja, sedangkan UNICEF mendefinisikan anak adalah sebagai penduduk yang berusia antara 0 sampai dengan 18 tahun. Seorang anak bisa dikatakan tumbuh apabila anak tersebut mengalami perubahan pada fisiknya yang dapat diukur secara kuantitas, sedangkan perkembangan bisa dilihat dari bertambahnya fungsi tubuh yang lebih kompleks seperti kemampuan gerak kasar, gerak halus, bicara dan bahasa, serta sosialisasi dan kemandirian (Depkes RI, 2006). Apabila mental anak berkembang secara matang maka pengaturan emosi, berpikir, dan adaptasi anak terhadap lingkungan akan baik, tetapi apabila perkembangan mentalnya mengalami keterlambatan maka akan terjadi gangguan perkembangan pervasif diantaranya adalah Down Syndrom dan retardasi mental (Maslim, 2003).

Retardasi mental tergolong gangguan

Aksis II yang didefinisikan dalam Diagnostic and Statistical Manual of Mental Disorders, 4th Edition, Text Revision (DSMIV-TR) sebagai fungsi intelektual yang sangat dibawah rata-rata, kurangnya prilaku adaptif, dan terjadi sebelum usia 18 tahun

Hasil studi Bank Dunia menunjukkan, Global Burden of Disease akibat masalah kesehatan mental mencapai $8,1 \%$. Menurut World Health Organization (WHO) tahun 2011, berdasarkan standar skor dari kecerdasan kategori American Association of Mental Retardation (AAMR) gangguan mental manual klasifikasi penyakit menempati urutan kesepuluh di dunia. Angka kejadian retardasi mental diberbagai negara berkembang secara umum berkisaran 1-3\% setiap populasi

Prevalensi penduduk di Indonesia yang mengalami retardasi mental menurut data semua provinsi yang ada di Indonesia dan jenis kecacatannya pada tahun 2000 adalah 189.625 orang atau $12,72 \%$ sedangkan hasil sensus penduduk Indonesia tahun 2009 menunjukkan bahwa jumlah anak retardasi mental sebanyak 66.610 anak

Berdasarkan data tersebut, anak dengan retardasi mental perlu mendapatkan perhatian serta dukungan yang lebih dari keluarga terutama orang tua, karena anak dengan retardasi mental memiliki tingkat ketergantungan terhadap orang tua dalam hal memenuhi kebutuhannya, sedangkan yang terjadi pada orang tua yang memiliki anak retardasi mental mengalami peningkatan beban orang tua, hal tersebut dapat memicu munculnya masalah psikososial yaitu kedua orang tua mengalami kecemasan.

Reaksi umum yang terjadi pada orang tua yang mempunyai anak retardasi mental pertama kali adalah merasa syok, mengalami goncangan batin, takut, sedih, kecewa, merasa bersalah, malu, dan menolak karena sulit mempercayai keadaan anaknya (Hasanah dkk, 2015).

Kondisi orang tua yang memiliki anak retardasi mental dapat mempengaruhi konsep 
dirinya. Konsep diri merupakan gambaran yang dimiliki seseorang tentang dirinya, yang dibentuk melalui pengalaman yang diperoleh dari interaksi dengan lingkungan (Agustiani, 2009). Konsep ini bukan merupakan faktor bawaan, melainkan berkembang dari pengalaman yang terus menerus. Konsep diri terdiri dari citra tubuh (Body Image), ideal diri (Self Ideal), harga diri (Self Esteem), peran (Self Role), identitas (Self Identity).

Kecemasan memiliki anak retardasi mental menjadi ketakutan yang nyata dialami oleh keluarga khususnya seorang ibu yaitu melahirkan bayi dengan keadaan fisiknya yang cacat. Kecemasan yang terdapat pada penelitian (Norhidayah, 2013) yang menunjukan bahwa salah satu permasalahan kecemasan ditinjau dari segi resiko berulangnya kelainan retardasi mental pada anak selanjutnya, sedangkan menurut penelitian (Hastuti, 2014), menunjukan bahwa permasalahan yang banyak di alami oleh orang tua khususnya seorang ibu dari anak retardasi mental adalah mengacu pada tingkah laku emosi anak retardasi mental, masalah keuangan, kemudian kemandirian anak, dan masa depan anak, sehingga keluarga menyekolahkan anak dengan retardasi mental ke sekolah luar biasa dengan harapan bisa meningkatkan perkembangan anak.

Data yang diperoleh dari SLB B-C Kurnia Kersamanah Garut pada tanggal 29 Januari 2018, didapatkan data dengan jumlah siswa yang mengalami retardasi mental sebanyak 54 orang. dibandingkan dengan 2
SLB yang lain dengan data yang di dapatkan dari SLB B-C YGP Cibatu sebanyak 28 orang dan di SLB BC Bandrek sebanyak 22 orang yang mengalami retardasi mental. Masalah yang ditemukan pada saat pengambilan data di SLB B-C Kurnia Garut, terdapat 7 anak yang tidak diantar ke sekolah oleh orang tuanya melainkan dititipkan ke orang lain, selain itu didapatkan keluarga siswa mengalami perasaan malu, dan merasa tidak punya harapan karena mempunyai anak retardasi mental, kemudian keluarga juga merasa harga diri keluarga jadi menurun karena mempunyai anak retardasi mental, keluarga khususnya seorang ibu memiliki perasaan dirinya berbeda dengan orang lain dan merasa telah gagal menjadi seorang ibu karena tidak bisa membesarkan anak layaknya anak normal lainya.

Hasil wawancara yang didapatkan dari 5 orang tua, mengatakan mereka merasa kecewa, malu, dengan Gen yang dimilikinya sehingga menghasilkan keturunan yang tidak normal, orang tua mengatakan ingin sekali memiliki anak normal seperti yang dimiliki orang tua lainnya, kemudian mengatakan sebagai ayah dan ibu mereka merasa tidak bangga memiliki anak retardasi mental karena beranggapan orang - orang yang berada di sekeliling atau lingkungan sosialnya tidak mau menerimanya dengan baik, selain itu, orang tua cenderung merasa memiliki anak retardasi mental selalu jadi penghalang dalam beraktivitas sehari hari, kemudian merasa memiliki anak retardasi mental menghalanginya untuk bergaul 
dengan orang orang yang ada di sekelilingnya, sehingga mereka merasa pesimis menjadi ayah dan ibu yang baik bagi anaknya, orang tua mengatakan memiliki anak retardasi mental tidak menjadikannya sebagai orang tua seutuhnya dan merasa gagal karena tidak bisa memiliki anak yang normal. Selain itu mereka merasa tidak bisa menerima kehadiran anaknya karena tidak sesuai dengan harapan mereka.

Hasil studi pendahuluan yang dilakukan kepada orang tua anak dengan retardasi mental juga mendapatkan beberapa keluhan, orang tua merasa bingung karena anaknya memiliki keadaan yang tidak sempurna, sehingga menyebabkan orang tua mengalami sulit tidur pada saat malam hari apabila memikirkan kondisi anaknya tersebut, selain mengalami kesulitan tidur orang tua juga mengalami sulit untuk berkonsentrasi dan mengalami hambatan dalam melakukan aktivitas sehari hari pada saat anaknya diluar rumah bersama orang lain karena khawatir terjadi hal hal buruk pada anaknya, selain itu orang tua mengatakan sering gelisah dan mudah tersinggung ketika ada orang lain yang menanyakan tentang kondisi anaknya, sehingga orang tua mengalami rasa takut tidak bisa mengurus dan mendidik anaknya dengan baik, karena anak retardasi mental dianggap oleh orang tua akan mengalami masalah pada karier anaknya, dan orang tua juga merasa takut anaknya sulit untuk mencapai masa depan yang cerah karena keterbatasan yang dimilikinya.
Berdasarkan uraian permasalahan tersebut, maka peneliti tertarik melakukan penelitian tentang gambaran konsep diri dan kecemasan pada orang tua yang memiliki anak retardasi mental di sekolah luarbiasa BC kurnia kabupaten garut.

\section{METODE}

Jenis penelitian yang digunakan dalam penelitian ini adalah deskriptif kuantitative, Populasi dalam penelitian ini yaitu orang tua yang memiliki anak retardasi mental sebanyak 54 orang Sampel penelitian sebanyak 54 orang tua yang memiliki anak retardasi mental. Instrumen yang telah digunakan dalam penelitian ini adalah kuesioner konsep diri yang telah baku dengan nilai uji validitasnya 0,66 dan kuesioner kecemasan Dass

\section{HASIL DAN PEMBAHASAN}

Hasil penelitian dan pembahasan tentang Gambaran Konsep Diri Dan Kecemasan Pada Orang Tua Yang Memiliki Anak Retardasi Mental Di Sekolah Luar Biasa B-C Kurnia Kabupaten Garut. Berikuti ini gambaran konsep diri orang tua yang memiliki anak retrdasi mental. 
Tabel 1 Distribusi Frekuensi Konsep Diri Pada Orang Tua yang Memiliki Anak Retardasimental di Sekolah Luar Biasa B-C Kabupaten Garut

\begin{tabular}{cccc}
\hline No & Kategori & Frekuensi & \% \\
\hline 1 & Positif & 39 & 72,2 \\
2 & Negatif & 15 & 27,8 \\
\hline & Total & $\mathbf{5 4}$ & $\mathbf{1 0 0 , 0}$ \\
\hline
\end{tabular}

Berdasarkan tabel 1 dapat dilihat bahwa 39 orang $(72,2 \%)$ memiliki konsep diri positif.

\section{Tabel 2 Distribusi Frekuensi Kecemasan Pada Orang Tua yang Memiliki Anak Retardasi mental di Sekolah Luar Biasa B-C Kabupaten Garut}

\begin{tabular}{cccc}
\hline No & Kategori & $\begin{array}{c}\text { Frekuen } \\
\text { si }\end{array}$ & \% \\
\hline 1 & Ringan & 1 & 1,9 \\
2 & Sedang & 25 & 46,3 \\
3 & Berat & 17 & 31,5 \\
4 & Sangat & 11 & 20,4 \\
& Berat & & \\
\hline & Total & $\mathbf{5 4}$ & $\mathbf{1 0 0 , 0}$ \\
\hline
\end{tabular}

Berdasarkan tabel 2 dapat dilihat bahwa 25 orang $(46,3 \%)$ memiliki kecemasan sedang.

Tabel 1 menunjukkan bahwa orang tua yang memiliki anak retardasi mental memiliki konsep diri positif, yakni sebanyak 39 orang atau $(72,2 \%)$. Benny, Nurdin, dan Chundrayetti (2014) mengatakan banyak ibu yang memiliki anak retardasi mental tidak memperlihatkan indikasi penolakan terhadap anak, disamping itu ibu menunjukkan perhatian dan cinta yang besar terhadap anaknya karena faktor terbesar yang melatarbelakangi penerimaan ibu adalah agama, dimana orang tua yang lebih intens dalam melakukan praktek agama cenderung bersikap lebih menerima anak-anak mereka yang terhambat secara fisik dan mentalnya. Hal ini juga didukung oleh Listiyaningsih dan Dewayani (2009) yaitu faktor lingkungan memberikan pengaruh paling besar terhadap kepercayaan diri orang tua dari anak retardasi mental, faktor lingkungan dapat diartikan sebagai lingkungan sosial, yaitu keberadaan orang-orang di sekitar orang tua anak retardasi mental, misalnya : tetangga, keluarga, dan anggota masyarakat yang lain dapat mendukung orang tua tersebut.

Berdasarkan tabel 2 menunjukkan bahwa orang tua yang memiliki anak retardasi mental memiliki tingkat kecemasan sedang sebanyak 25 responden (46,3\%). Dari hasil penelitian dilapangan mengenai tingkat kecemasan sebagian besar menunjukan bahwa orang tua berada dalam kategori kecemasan sedang. Hal ini kemungkinan sangat dipengaruhi oleh faktor kesehatan yang baik secara fisik, psikis, maupun sosial. Kondisi sehat yang baik pada orang tua yang memiliki anak retardasi mental seperti tidak menglami ganguan ketika memperhatikan sesuatu, memiliki konsentrasi yang baik, tidak mudah lupa, memberikan penialaian objektif, sangat waspada, dan kesadaran diri meningkat, sedangkan orang tua yang mengalami kecemasan berat sebanyak 17 $(31,5 \%)$, Kecemasan yang terjadi pada ibu penderita retardasi mental disebabkan oleh permasalahan yang ditimbulkan karena memiliki anak retardasi mental itu lebih kompleks dibandingkan dengan ibu yang memiliki anak normal. Kecemasan yang 
dialami seorang ibu yang memiliki anak yang berkebutuhan khusus merupakan jenis kecemasan realitas. Hal yang juga menyebabkan sebagian besar ibu penderita retardasi mental mengalami kecemasan adalah kemungkinan adanya konflik dalam menghadapi anak retardasi mental, seringkali orang tua tidak memahami tentang kondisi anaknya dengan retardasi mental, sehingga mereka merasa bimbang terhadap kondisi anaknya dan mengalami konflik dalam diri. Konflik juga berpotensi terjadi karena adanya perbedaan penanganan terhadap anak retardasi mental dengan anak normal pada umumnya, selain itu kecemasan yang terjadi pada orang tua dengan anak retardasi mental karena adanya tingkat usia dan tahapan hidup yang berbeda sehingga hal tersebut dapat mempengaruhi persepsi pemahaman dan penerimaan anak retardasi mental.

\section{KESIMPULAN}

Berdasarkan hasil analisa dan pembahasan penelitian dapat disimpulkan bahwa :

1. Gambaran konsep diri orang tua yang memiliki anak retardasi mental di SLB B-C Kurnia Kabupaten Garut, berada dalam kategori positif yaitu 70,9\% .

2. Gambaran kecemasan orang tua yang memiliki anak retardasi mental di SLB B-C Kurnia Kabupaten Garut, dari responden memiliki tingkat kecemasan sedang yaitu $45,5 \%$.

\section{SARAN}

\section{Sekolah Luar Biasa}

Mempunyai konsep diri positif dan kecemasan sedang yang dimiliki orang tua, diharapkan pihak sekolah selalu berkoordinasi dengan puskesmas untuk memberikan penyuluhan atau konseling kepada orang tua yang memiliki anak retardasi mental.

\section{Puskesmas UPT Sukamerang}

Sesuai dengan hasil penelitian didapatkan bahwa konsep diri keluarga yang memiliki anak retardasi mental memiliki konsep diri yang positif dan mengalami kecemasan sedang, oleh karena itu petugas kesehatan diharapkan agar dapat mempertahankan dan meningkatkan peran sertanya dimasyarakat dalam memberikan informasi kesehatan berupa penyuluhan, khususnya mengenai kesehatan anak retardasi mental dan memberikan motivasi kepada keluarga sehingga mereka dapat mengambil keputusan dan mau memberikan pendidikan dan terapi untuk anak retardasi mental.

\section{Penelitian Selanjutnya}

Penelitian selanjutnya disarankan untuk melakukan penelitian tentang faktorfaktor yang mempengaruhi konsep diri dan kecemasan keluarga yang memiliki anak retardasi mental atau anak berkebutuhan khusus lainnya. 


\section{DAFTAR PUSTAKA}

Abdul Muhith. 2015 Pendidikan Keperawatan Jiwa Teori Dan Aplikasi Yogyakarta : andi offset

Abdul Nasir \& Abdul Muhith, 2011 DASARDASAR KEPERAWATAN JIWA Jakarta :salemba medika

Arikunto, S. 2012. Prosedur Penelitian Suatu Pendekatan Praktik. Penerbit Rineka Cipta. Jakarta

Ayu Ariesta, A., 2016. KECEMASAN ORANG TUA TERHADAP KARIER ANAK BERKEBUTUHAN KHUSUS (Doctoral dissertation, Fakultas Ilmu Pendidikan).

Aziz Alimul Hidayat 2008 Ilmu Kesehatan Anak Untuk Pendidikan Kebidanan jakarta : salemba medika

Benny, F., Nurdin, A.E. and Chundrayetti, E., 2014. Penerimaan Ibu yang Memiliki Anak Retardasi Mental di SLB YPAC Padang. Jurnal

Kesehatan Andalas, 3(2).

Depkes. (2009). Anak Dengan Tunagrahita Perlu Pendekatan Khusus. Diunduh 12 februari 2018, depkes.go.id.

Faradina, N., 2016. Penerimaan Diri Pada Orang Tua Yang Memiliki Anak Berkebutuhan Khusus. Ejournal Psikologi, 4(4), pp.386-396.

Hamacek,D 1990., Psychology In Teaching, Learning And Growth, Needham Heights Massachusetts : Allyn And Bacon

Kozier, Erb, Berman \& Snyder. 2010. Fundamental keperawatan: konsep, proses, \& praktek, Edisi 7. Alih bahasa oleh Widayanti, E. Jakarta: EGC.

Jhonson, L., Leny R. (2010). Keperawatan Keluarga: Plus Contoh Askep Keluarga. Yogyakarta: Nuha Medika.

Jurnal Penelitian Kesehatan STIKes Dharma Bandung
Lisnayanti, N. W., \& Lisnayanti, N. W. (2015). Hubungan Tingkat Harga Diri (Self-Esteem) dengan Tingkat Ansietas Orang Tua Dalam Merawat Anak Tunagrahita di SDLB C Negeri Denpasar (Doctoral dissertation, Universitas Udayana).

Listiyaningsih, R. and Dewayani, T.N.E., 2010. Kepercayaan diri pada orangtua yang memiliki anak tunagrahita.

Maslim, Rusli. 2003 Diagnosis gangguan jiwa, rujukan ringkas PPGD III. Jakarta : bagian ilmu kedokteran jiwa FK- unika atmaja

Nitra Fitria, Aat Sriati, Taty Hernawaty, 2012 Laporan Pendahuluan Tentang Masalah Psikososial Jakarta: salemba medika

Norhidayah, N., Wasilah, S., \& Husein, A. N. (2016). Gambaran Kejadian Kecemasan Pada Ibu Penderita Retardasi Mental Sindromik Di Slb-C Banjarmasin: Tinjauan Terhadap Usia Anak, Paritas Dan Tingkat Pendidikan Ibu. Berkala Kedokteran, 9(1), 43-50.

Notoatmodjo, S. 2010. Metodologi Penelitian Kesehatan. Jakarta: EGC

Onong uchjana Effendy. 2006. Ilmu Komunikasi; Teori dan Praktek. Bandung: Penerbit Remaja Rosda Karya

Pieter, Herri Zan., Janiwarti, Bethsaida, \& Saragih, Marti. (2011). Pengantar Psikopatologi untuk Keperawatan. Jakarta: Kencana

Pieter, Zan Herri. \& Lubis, Namora Lumanggo. (2010). Pengantar Psikologi Dalam Keperawatan. Jakarta : Kencana.

Potter, P.A., \& Perry, A.G. (2009). Fundamental Keperawatan Buku 1 Ed 7. Alih bahasa oleh Renata Komalasari. Jakarta: Salemba Medika. 
Purba, Jenny Marlindawani., Wahyuni, Sri Eka., Daulay, Wardiyah., \& Nasution, Mahnum Lailan. (2012). Asuhan Keperawatan pada Klien dengan Masalah Psikososial dan Gangguan Jiwa. Medan : USU Press.

Rahmah, H., 2004. Zamralita. "Penyesuaian Diri Orang Tua yang Memiliki Anak Retardasi Mental Ringan. Jurnal Ilmiah Psikologi” ARKHE, 9(2), pp.90-100.

Salbiah. (2003). Konsep Diri. Dapat diakses di http://repository.usu.ac.id/di buka 26 februari 2018
Siregar Alfriani, V. (2016) “Gambaran konsep Diri pada Orang Tua yang memiliki anak Retardasi Mental di Yayasan Pembinaan Anak Cacat (YPAC)" Kota Medan

Sugiyono. (2016). Metode Penelitian Kuantitatif, Kualitatif dan $R \& D$. Bandung: PT Alfabet.

Suliswati. dkk., (2005). Konsep Dasar Keperawatan Jiwa. Jakarta: EGC

Tarwoto \& Wartonah. (2010). Kebutuhan Dasar Manusia dan Proses Keperawatan. Jakarta : Salemba Medika. 